April 2011

\title{
Critical Reflections on MARO: The View from Argentina
}

Federico Gaitan Hairabedian

Alexis Papazian

Follow this and additional works at: https://digitalcommons.usf.edu/gsp

\section{Recommended Citation}

Hairabedian, Federico Gaitan and Papazian, Alexis (2011) "Critical Reflections on MARO: The View from Argentina," Genocide Studies and Prevention: An International Journal: Vol. 6: Iss. 1: Article 6.

Available at: https://digitalcommons.usf.edu/gsp/vol6/iss1/6

This Articles is brought to you for free and open access by the Open Access Journals at Digital Commons @ University of South Florida. It has been accepted for inclusion in Genocide Studies and Prevention: An International Journal by an authorized editor of Digital Commons @ University of South Florida. For more information, please contact digitalcommons@usf.edu. 


\title{
Critical Reflections on MARO: The View from Argentina
}

\author{
Federico Gaitan Hairabedian \\ University of Buenos Aires and Luisa Hairabedian Foundation
}

\author{
Alexis Papazian \\ University of Buenos Aires, CONICET, and \\ Luisa Hairabedian Foundation
}

\section{Introduction}

The following commentary aims to analyze the main characteristics of intervention described in MARO: Mass Atrocity Response Operations; A Military Planning Handbook and to also provide a legal and historical context in which to address that work. In other words, we believe that in order for the inner value of $M A R O$ to be assessed, the handbook should be contextualized with the history of American intervention and several aspects of international law.

First, it is important to provide the context in which this article was produced. On the one hand, we promote interdisciplinary work, especially work on law and history, since it enriches perspectives, contributions, and opinions. On the other hand, because we are from Argentina we might offer a different perspective on intervention operations in general and on MAROs in particular. That is to say, living in and being part of a developing region give us the opportunity to offer different opinions on intervention practices. It is also necessary to make it clear that because our professional training is not of a military nature we are not able to provide an indepth analysis of the action plan described in $M A R O$, particularly regarding the operative aspects that were formulated by military strategy experts. These limitations, however, do not push us away from our objective; rather, they bring us closer to it. This commentary does not intend to provide instructions on how to conduct a military operation in cases of massive crimes; rather, it intends to investigate whether a MARO constitutes an ethical and moral option and whether it is the best practical way to avoid, prevent, and control crimes against humanity (such as genocides, massacres, and war crimes). Although $M A R O$ intends to describe the military actions to be taken in cases of massive crimes, there is a lack of introspective and selfreflexive analysis of American interventions in the handbook along with a unilateral view, created by US military forces, of the operating methods in these situations. Both of these aspects compel us to combine a historical perspective with a legal one in our consideration of $M A R O$.

Taking into account the observations made above, we divided this commentary into three sections and a final conclusion. In the following section we provide a short analysis of different American military interventions, focusing on the way they unfold in the intervention regions. The second section deals with intervention and considers the legal contributions and change in paradigm after the dissolution of the Soviet Union. The last section concentrates on the concept of a MARO, providing

Federico Gaitain Hairabedian and Alexis Papazian, "Critical Reflections on MARO: The View from Argentina," Genocide Studies and Prevention 6, 1 (April 2011): 45-51. (C) 2011 Genocide Studies and Prevention. doi:10.3138/gsp.6.1.45 
a critical analysis of the contents of the book in question, especially of the role of international organizations and local agencies. Apart from reconsidering action plans and interventions in cases of mass crimes against civil society for future discussions, we discuss the controversy that surrounds this issue.

\section{A Short History of American Interventions}

The United States is the country that has intervened most often in the affairs of other states in the world. Those interventions were responses, in general terms, to interests related to external policies and/or economic interests over the affected nation.

The purpose of this section is to place $M A R O$ into a historical context. By doing so, we may find that $M A R O$ has hidden intentions under its pragmatic proposal to provide instructions on "how" to militarily intervene in cases of massive crimes against a civil society.

We can go back in history to the year 1916 as the starting point of this issue. Beginning in this year, American military forces occupied the Dominican Republic for eight years because it got into arrears with a loan. The formal declaration stated:

Dominican Republic is in a state of military occupations ... and remains submitted to the military government and to the exercise of the military Law applicable to such occupation. This military occupation has not the purpose of destroying Dominican Republic sovereignty, but on the contrary, is intended to help the country to recover the internal order condition, what will be helpful to fulfill provisions stated on the named Convention, and also to comply with all obligations that may correspond as member of Nations Family.... I ask all Dominican citizens ... to cooperate with US Forces in occupation. ${ }^{1}$

After the Second World War, the United States intervened directly in more than eighty countries (this figure includes cases of joint and unilateral interventions). Most of these interventions were linked to the Cold War against USSR Communism. As examples we can mention interventions like the Chinese Civil War (1945-1949), interventions in Italy (1947-1948), Greece (1947-1949; 1964-1974), Philippines, Korea, Iran (together with England in 1953), Guatemala (1953-1990), Vietnam (1950-1973), Cambodia (1955-1973), Congo/Zaire (1960-1965), Indonesia (1965), Nicaragua (1978-1979), Granada (1979-1984), El Salvador (1980-1992), Haiti (1987-1994). Notably, we are not taking into consideration indirect interventions that, just to give an example, provided support (i.e., military intelligence) to several leaders that governed in Latin America during different military dictatorships.

Looking back to the history of interventions, especially in the areas of Latin America, Africa, and the Middle East, should call the attention of MARO's authors to the nature of intervention and its historical effects. It can be stated that the current situation is different from that in the time of the Cold War, but the traumatic effects of interventions do not disappear with time and can be used against American forces. In other words, as professionals trained in Argentina, we wonder why it is that the MARO project would have better results in preventing, controlling, and stabilizing countries where massive crimes against civil society are committed and if such would indeed be the case. The answer is open to the (dis)trust that the United States inspires in peripheral countries. MARO does not take into account historical characteristics of each country, and even if the project centers its efforts on the analysis of the nation in which the intervention is to occur and even if assistance to the transition government is part of its stabilizing practice (55-58), 
it nevertheless subsumes the role that the intervened nation adopts into its own operating power.

\section{Legal Aspects of Intervention}

\section{The Difference between "Humanitarian Intervention" and "Humanitarian Action"}

Within the framework of Public International Law there exists a substantial distinction between the concept of "humanitarian intervention" and that of "humanitarian action." Even if we can distinguish between two fundamental approaches within this topic, such as International Law of Human Rights and International Humanitarian Law, both seem to come together when dealing with issues related to intervention. What is important to underline is that "intervention" is in general a broader concept than the concept of humanitarian military intervention since the latter refers strictly to direct and exclusive armed action. Meanwhile, when we talk about humanitarian action in a strictly judicial sense, we refer to the actions considered by International Humanitarian Law as assistance law that can guide organizations like the International Red Cross. On the other hand, a clear example of humanitarian military intervention is the case of NATO's intervention in Kosovo.

Humanitarian military intervention and humanitarian action are similar in that they are both used as ultima ratio, that is to say, when there are no other ways of solving the consequences of a conflict.

It is important to highlight the internal contradiction between the use of forces and the humanitarian motive. The exercise of military force can never constitute a humanitarian act, even when it uses humanitarian discourse to justify its repressive action.

Thus, from a juridical point of view as well as that of the conceptual principles of Public International Law, a humanitarian intervention may constitute an exception to the three most consolidated principles of international law: (1) state sovereignty; (2) the principle that one state should not intervene in the internal issues of other states; and (3) the prohibition of the use of armed forces. ${ }^{2}$

These three principles constitute the basic pillar of international relations and they are stated in the United Nations Charter. The Charter does not refer explicitly to humanitarian intervention, but in regards to the use of force the Charter provides the Security Council with the option to adopt two types of measures, which are outlined in Chapter VII, particularly in Articles 41 and 42 of the Charter. ${ }^{3}$ Article 41 specifies the measures that can be applied without armed forces (such as the complete or partial interruption of communications, economic activities, or diplomatic relationships), and Article 42 describes the measures that can be used involving the participation of armed forces and states (such as demonstrations, blockades, and military operations such as those in Somalia, the former Yugoslavia, and so forth).

After the dissolution of the Soviet Union and the development of a globalized world, the idea of humanitarian military intervention, including in some cases unilateral military intervention, was put into practice in several cases such as Somalia (1992-1995), Bosnia and Herzegovina (1992-1995), Rwanda (1994), Sierra Leone (1997-1999), Kosovo (1996-1999), Liberia (1999-2003), and the Congo (1998present).

Taking into consideration the elements stated above raises questions about the effect of intervention on state sovereignty. 


\section{The Responsibility to Protect (R2P) and the MARO Project versus State Sovereignty}

The increasing importance of humanitarian military intervention and the potential risk of this principle becoming an international practice that may threaten state sovereignty are publicly debated.

The type of interventions mentioned above occurred within the dissolution of the Soviet Union and the deepening neoliberal policies of the capitalist system and its political consequences, especially these consequences as they relate to the principle of state sovereignty at all levels.

Discussions about intervention in cases of humanitarian crises may find their starting point in the famous phrase of a former United Nations General Secretary, Koffi Annan: “... if humanitarian intervention is, indeed, an unacceptable assault on sovereignty, how should we respond to a Rwanda, to a Srebrenica-to gross and systematic violations of human rights that affect every precept of our common humanity?"4

After the debate generated by this issue, Canada was the head office of the International Commission on Intervention and State Sovereignty (ICISS) where two main basic principles were defined in order to justify the doctrine of Responsibility to Project $(\mathrm{R} 2 \mathrm{P})^{5}$ : first, state sovereignty implies responsibility, and the primary responsibility for the protection of its people lies with the state itself, and second, when a population is suffering serious harm as a result of internal war, insurgency, repression, or state failure, and the state in question is unwilling or unable to halt or avert it, the principle of non-intervention yields to the international responsibility to protect.

Even though the MARO project states that it does not defend military intervention and that its action field is confined to cases of extreme need, like cases of genocides and mass killings, the R2P doctrine is the basis of its ideological support.

The document outlined by ICISS represents a "before and after" in the conception of state sovereignty and military intervention as it tries to create a new vocabulary by which to define antique practices and justify the change of paradigm towards a global world which would include a project such as $M A R O$ as an operative tool but restricted to extreme cases.

R2P and the MARO project are perfect expressions of global strategies of unilateral action for military intervention. Proof of this became evident, for the first time, when NATO bombed Serbia's position in Kosovo after approving the New Strategic Concept in April 1999.

The New Strategic Concept redefined NATO's future objectives, methodology, and scope of action. The main way in which NATO was transformed was in its move from defensive objectives to the assumption of the essential mission of defending security and democratic values within and outside its boundaries, a mission that includes a struggle against genocide, terrorism, and the elimination of weapons of mass destruction. Further, tensions existing between the development of R2P and principles of state sovereignty can be understood under the New Strategic Concept which allowed NATO to retain its right to act without the formal authorization of the United Nations Security Council provided that its actions respect the Organic Charter or the Council Resolutions. In this way, NATO obtained its own unilateral humanitarian intervention right disregarding all emerging principles of the United Nations Charter which stipulated that regional organizations should not apply any coercive measure without the consent of the Security Council. 
All of the changes mentioned occurred after the end of the Cold War as the United States emerged as a dominant world power. As an example, we can recall that it acted above the United Nations in the case of the "preventative attack" of Iraq.

As a conclusion, we can observe that the role played by the United Nations became of secondary importance in the world despite the end of the Cold War and the dissolution of the absolute principle of state sovereignty.

In relation to this last point, the concept of national sovereignty raises another issue. Although various states guarantee that they will observe the principles of international law and human rights protection, most states are increasingly inclined toward the consolidation of a globalized system in which transnational economic power operates by means of supranational organizations like the World Trade Organization, World Bank, and International Monetary Fund. The classic concept of nation-state as it was understood at the moment when the United Nations Charter was approved in 1946 is no longer valid.

The authority of the United Nations is fundamental in order to avoid the consolidation of a power axis capable of intervening unilaterally in sovereign states either under the doctrine of R2P or within a MARO framework. However, the United Nations Security Council is under the domain of the same powers that retain unilateral intervention capability, a paradox that presents a situation with little space of action. It is time to rebuild and strengthen the United Nations in order to allow for a plurality of voices and especially to allow the voices of those weak states that face the potential risk of genocide and massive violations of human rights to be heard.

Acting outside of the framework of international law can contribute to the discredit of legal entities; eventually, subjects of international law may be deprived of judicial protection and, instead, the unilateral decisions of powerful states can come to dominate the international arena.

\section{Shoot MARO Heart: The Utility of Unilateral Intervention Practice ${ }^{6}$}

$M A R O$ is presented as a potential military doctrine for the use of American armed forces in cases of massive human rights violations. What the handbook's authors consider its key virtue is actually a fallacy: $M A R O$ does not question whether an intervention should take place, but only "how" to intervene. ${ }^{7}$ Certainly, in situations of extreme violence over a civil society in which the rate of massive killings multiplies at a rapid pace, and especially in cases when states' governments are involved as perpetrators of violence, wondering whether to intervene or not to intervene can be a useless question, as cases such as those of Rwanda, Darfur, and Kosovo evidenced. However, it is also dangerous to assume that it is necessary to intervene unilaterally in regions that historically and culturally differ from the American egocentric thinking and/or consider American military action as an imperialistic advance over the self-determination of nations. Like many other American humanitarian organizations, they ask for military intervention in regions in which massive crimes occur (13). Other humanitarian NGOs, however, disagree with the American army assuming for itself the role of democracy's spokesperson.

The fundamental questions in order to determine if a MARO is legally accepted by nations and societies are, first, questions about who should intervene. Once this is established, we can then wonder how to intervene. The unilateral intervention of the United States and its allies, such as NATO, cannot be considered as a humanitarian practice but as a hegemonic expansion over states with less democratic stability. 
Again, we can go over the analysis of the discord between MARO discourse and the real interest of American interventions in the world. Following this question, a MARO organization chart (58) proposes that the United States becomes the potential figure of a Military Allied Committee. The real hierarchical relationship between international and local allies is confined to coordination spaces.

It is perhaps unnecessary to specify that we are skeptical of the MARO project. However, in regards to intervention, both the role of the United States and that of the nations involved directly or indirectly in crimes against humanity or genocide need to be considered.

We believe that it is necessary to stay away from hypocritical speeches that talk about nations' need of Democracy and Freedom to operate with legitimacy in order to guarantee the protection of inhabitants within their borders and to provide diversity of thinking and actions outside of their boundaries by means of the United Nations.

We think it is necessary to direct attention to new intervention locations. In other words, intervention is not only necessary in areas that are destroyed by genocides and in suffering countries; rather, intervention is also necessary where the material tools used to perform mass killings and genocides (weapons, soldiers) are being manufactured, even if intervening involves dealing with a world-wide, multi-million-dollar business. In conclusion, it is time to start considering how many and what types of intervention are necessary. It is time to understand that massacres in a distant place may have responsible actors in the industries of the central countries.

\section{Notes}

1. Harry S. Knapp, American Proclamation of Intervention, 29 November 1916, quoted in "La justicia durante la intervención norteamericana" [Justice during the American Intervention], trans. Federico Gaitan Hairabedian and Alexis Papazian, http://suprema. gov.do/PDF_2/publicaciones/libros/historia_poder_judicial/Capitulo_XII.pdf.

2. Luis A. Podestá Costa and José María Ruda. Derecho Internacional Público [Public International Law] (Buenos Aires: Tipográfica Editora Argentina, 2000).

3. Article 41 of the Charter states: "The Security Council may decide what measures not involving the use of armed force are to be employed to give effect to its decisions, and it may call upon the Members of the United Nations to apply such measures. These may include complete or partial interruption of economic relations and of rail, sea, air, postal, telegraphic, radio, and other means of communication, and the severance of diplomatic relations." Article 42 continues, "Should the Security Council consider that measures provided for in Article 41 would be inadequate or have proved to be inadequate, it may take such action by air, sea, or land forces as may be necessary to maintain or restore international peace and security. Such action may include demonstrations, blockade, and other operations by air, sea, or land forces of Members of the United Nations." "Chapter VII: Action with Respect to Threats to the Peace, Breaches of the Peace, and Acts of Aggression," Charter of the United Nations, art. 41-42, http://www.un.org/en/documents/charter/chapter7.shtml.

4. At the United Nations General Assembly, Secretary-General Kofi Annan asked, "if humanitarian intervention is, indeed, an unacceptable assault on sovereignty, how should we respond to a Rwanda, to a Srebrenica-to gross and systematic violations of human rights that affect every precept of our common humanity?" Quoted in Gareth Evans and Mohamed Sahnoun, Co-Chairs, The Responsibility to Protect: The Report of the International Commission on Intervention and State Sovereignty, (Ottawa, ON: International Development Research Centre, December 2001), vii.

5. The ICISS report states, "Our mandate was generally to build a broader understanding of the problem of reconciling intervention for human protection purposes and sovereignty; 
more specifically, it was to try to develop a global political consensus on how to move from polemics-and often paralysis - towards action within the international system, particularly through the United Nations." Evans and Sahnoun, The Responsibility to Protect, vii.

6. By "unilateral actions," we mean those not taken within the nations represented at an international level by United Nations.

7. Sarah Sewall, Dwight Raymond, and Sally Chin, MARO: Mass Atrocity Response Operations; A Military Planning Handbook (Cambridge, MA: Harvard Kennedy School / Carr Centre for Human Rights Policy, 2010), 5, 6, 12, 14, 52, 54. Subsequent references appear parenthetically in the text. 